\title{
THE BRITISH MONOPOLIES ACT OF 1948: A CONTRAST WITH AMERICAN POLICY AND PRACTICE
}

ON July 30, 1948, the British Parliament enacted Britain's first piece of generic antitrust legislation-the Monopolies and Restrictive Practices (Inquiry and Control) Act, 1948. I Under the Act, which had Conservative as well as Labor support, governmental power, working through an adminstrative Commission under the direction of the Board of Trade, has been specifically extended to strike against monopoly and restrictivism in British industry. ${ }^{2}$ The disease is as familiar as the remedy-undesirable business power is to be combatted with antitrust legislation. But the present doctor is a labor government dedicated to implementation of a monopolistic economy through nationalization, ${ }^{3}$ and the patient is an England gradually turning socialist. The Act may represent an attempt to create competition in the midst of monopoly. ${ }^{4}$ More likely, at least in the hands of a labor government, it is designed to serve as a procedural facade from behind which further government controls can be extended over those sectors of British industry as yet not nationalized. ${ }^{5}$ In any case, the tra-

1. 11 \& 12 Gko. 6,1948 , c. 66 (hereafter referred to as Mlonopolies Act). The Act was supported by the Conservative and Liberal Parties, as well as the Labour Party, and was passed unanimously. 452 H.C. DEB. 2167 (5th ser. 1948). The somewhat clumsy title is the result of a compromise between the original plan for simply "MIonopolies Act," and the Conservative suggestion of "Restrictive Business Practices." 452 H.C. Den. 2082-8, 2166; 454 id. 1079-80 (5th ser. 1948). See Plant, Monopolics and Restrictive Practices, 10 Lloyds BanK Rev. 1 (1948). The title suggested by the Conservatives was criticized as an undesirable "Americanism" by MIr. Harold Wilson, President of the Board of Trade and chief sponsor of the Act. 452 H.C. DEB. 2086-7 (5th ser. 1948).

2. The preamble to the Act states that its purpose is "to make provision for inquiry into the existence and effects of, and for dealing with mischiefs resulting from . . . any conditions of monopoly or restriction or other analogous conditions. ..." Monopolies Act, 1948, 11 \& 12 GEo. 6, c. 66.

3. See, e.g., Letwis, Monopoly IN Brrish Industry 1 (Fabian Research Series No. $91,1945)$, denoting private monopoly as a problem to be handled during the interim period of private enterprise before nationalization can be effected.

4. See Meier, A Critique of the New British Mlonopoly Act, 48 MIrre. L. Rev. 329, 330 (1950) for the view that the Act is designed to restore competition to non-controlled sectors of the industry. That some factions within the Labour Party have supported this idea, see Stocking \& Watkins, Cartels or Coarpetition? 363 (1948).

5. See pages 904-5 infra. Independent critics in the laissez-faire tradition have complained the Act does too little against restrictivism and too much for the expansion of government power. Offensive Against Monopoly, 154 Ecovourss 574 (1948); see Cohen, The New British Law on Mronopoly, 39 Ass. Ecos. Rev. 485, 487-9 (1949). But the Conservative position varied little from that of the Labour Party, except for attacks of a political nature. See, e.g., Speech of Sir David Maxwell-Fyfe, 449 H.C. DEs. 203952 (5th ser. 1948). Their objections to the Act centered mainly around the exclusion of government monopolies and labor unions from its scope. See note 39 infra. Further Conservative proposals, if carried, would have weakened rather than strengthened the Act. See, e.g., Speech of Lyttleton, 449 H.C. DEB. 2110-22 (5th ser. 1948) (that the 
ditional basis of antitrust legislation-preservation of the competitive system ${ }^{6}$ - has given way before distrust of a free enterprise society and dependence on a centrally controlled "planned economy." 7

\section{Policy, Old AND NEW}

England has a long history of permitting the fact of monopoly to co-exist with the theory of competition. ${ }^{8}$ Despite her background of theoretical exaltation of the competitive system, Great Britain has never attempted to maintain competition through legislation.9 The Statute of Monopolies of $1624,{ }^{10}$ and its reenactment in the final abrogation of the royal prerogative in 1689 , were aimed only at the arbitrary grants of legal monopoly franchises by the Crown." 11 Since the time of those acts, throughout the disruptions

one-third criterion of monopoly "seems to have strayed into the Bill from fairyland or from the pages of Waiter de la Mare." The speaker was the Chairman of the Associated Electrical Industries.) ; $452 \mathrm{id} .2107-11$ (one-half proposed as an alternative to onethird).

6. For a condensed checklist of the basic theoretical assumptions behind American antitrust legislation, see Oppenteria, Cases on Federal ANTr-Trust Laws $91-9$ (1948).

7. See Joint Committee of the Labor Party and the Trades Union Congress on Trusts and Cartels, The Public Control of Monopoly (1947), quoted infra page 905; The Grouth Roots of Monopoly, 155 Econonust 619-20 (1948); cf. Lawis, Monopoly and the Law, An Economist's Reflection on the Crofter Case, 6 Mod. L. Rev. 97, 111 (1943).

The Conservative Party has from time to time talked in terms of "competition." Sce Speech of Anthony Eden in the N.Y. Times, Feb. 19, 1950, \$6, p. 7, col. 3; TonY Rx-

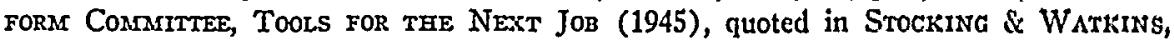
op. cit. supra note 4, at 361 . But the word must be read in its political context. Factually, it refers to an economy which, if it ever existed in Britain, was destroyed partially through Conservative acquiescence in, and assistance to, industrial combination. Sec, e.g., Stocking \& Watkins, op. cit. supra note 4, at 355-6; 156 Economist 95 (1949). As used currently, the word refers to an absence of outright nationalization, rather than the presence of either market or performance competition. For discussion of this point as related to the Monopolies Act, see note 5 supra and pages 904-5 infra.

8. See generally LuCas, Industrial Reconstruction aNd the Control of Conpetition 17-19 (1937) ; Maxwell-Fyfe, Monopoly (Conservative Political Centre, 1948); Stocking \& Watkins, Carteis or Competition? 342-72 (1948).

9. A Trust and Combines Bill was moved in 1925, but failed to get through. Sec Speech of Jones, 449 H.C. DEb. 2092-9 (5th ser. 1948).

10. 21 JAC. 1,1624 , c. 3.

11. The public had become incensed at the unrestrained creation of monopolies by Elizabeth and James I. When prior concessions made by Elizabeth to the anti-monopoly sentiment proved of little worth, the Statute of Monopolies was forced on the King. See, e.g., Levy, Monopolies, Cartels and Trusts in British Ixdustry 17-23 (2d ed. 1927).

The Statute codified the distinction between grants of monopoly in already existent businesses, and in new and useful inventions. The distinction had already been mado by the courts: Darcey v. Allein (the Case of Monopolies), 77 Eng. Rep. 1260 (K.B. 1602); The Clothworkers of Ipswich, 78 Eng. Rep. 147 (K.B. 1615) ; see Orpenuens, Cases on Federal ANTi-Trust Laws 467 (1948). This was the historical origin of 
of the industrial revolution and subsequent rise of trade combinations and integrated trusts, there has been no generic anti-monopoly legislation.

The absence of legislation did not mean the presence of competition. The British trend towards industrial combination post-dated the parallel movements in the United States and other nations. ${ }^{12}$ But loosely-knit price-fixing associations were in existence prior to $1880,{ }^{13}$ and following the depression of the 1890's, there was a strong swing towards industrial self-government, "rationalization," and suppression of "ruinous competition." 1" The velocity of the swing was increased by the exigencies of World War I; new combinations sprang up; old ones were strengthened and added to. ${ }^{15}$ The slight tendency towards a decentralizing backswing in the 1920's was halted abruptly by the slump of the 1930's. ${ }^{10}$ By the start of World IVar II, there

patent law. See Second Interas Report of the Departasentac. Cosontitee on Patents and Designs Act 3 (Card. No. 67S9, 1946) ; Handler, Patents aNd Free EitiesPRISE 11-18 (TNEC Monograph 31, 1941).

12. The first large closely-knit industrial combination was the Salt Union, which became prominent in 1888, when pressure for antitrust legisiation was already strong in America. The London Times, on Sept. 15, 18s8, called it "the great Salt Trust." 3 Claphan, Am Econonic History of Modern Britan 215 (1938). The Eco:ro:ust, in its Commerciar History of 18SS, p. 3, called upon Parliament to watch vigilantly the attempt to monopolize "what is really national property." See 3 CLAprAss, op. cit. sispro, at 215-6 (1938); Calvert, A History of the Salt Union (1913); MLAcrosty, The Trust Mioveanent in Britise Industry 182-6 (1907).

In America, Standard Oil, for example, had been in operation since 1870. Sce Standard Oil Co. of New Jersey v. United States, 221 U.S. 1, 5 (1911). The days of industrial piracy had started as soon as the Civil War had ended, and in many areas prior to 1890, "feudal domains" had been established by "the swashbucklling captains of industry." See Haximton \& Til, ANTitrust in Action 5 (TNEC Mfonograph 16, 1940).

13. See Papers of Comanttree on Trusts (1919), quoted in 3 Cunpenss, op. cil. supra note 12, at 302; MLACROSTy, op. cit. supra note 12, at 203 (Lever, founder of a corporation which at one time manufactured 70 to $75 \%$ of the total British soap production, quoted as saying in 1906 that there had been a "working arrangement in the trade for the past thirty years").

14. Complaints about the effect of "ruinous competition" had been heard in Parliament as eariy as 1833, and had been reiterated from time to time, especially by a Parliamentary Commission in 1886. LEvY, op. cit. supro note 11, at 169 . But, according to the report of an Industrial Commission created in 1898 by the United States Congress to study the general problem, the real British drive towards amalgamation did not occur until the end of the 90's. REPORT of THE INDUSTrLal Cossurssion v. XVIII, Industrial Combinations in Europe 14 (1901). For the story of the rise of industrial combination prior to World War I, see generally Carter, The Tendenct rowards Indusmina. CossBINATton (1913); 3 CiApEAar, op. cit. supra note 12, ce. 4-5; MlacrostY, op. cit. suspro note 12, at 24 et seq. See also REPORT of THE INDUStrinl Cosrsmssion, op. cit. sispra, at $14-74$.

15. See, e.g., Hilton, $A$ Study of Trade Organizations and Combinations in the Uniled Kingdont in RePort of Cosmuttee oN Trusts 15, 20 (Card. No. 9236, 1919); ReEs, Trusts IN BRITISH INDUSTRY (1922) passin; LEwIS, op. cit. supra note 3 , at 7.

16. See LEwIS, op. cit. supra note 3 , at 7-8; LuCss, op. cit. sipra note 8 , at $c 2$. 
was partial monopolistic control in almost every sector of the economy, and in some sectors the monopoly was practically complete. ${ }^{17}$

Against this tide stood the miniscule and leaky dam of the common law. In theory, contracts in restraint of trade were void, ${ }^{18}$ and damages suffered as a result of a conspiracy to restrain trade could be compensated through action in tort. ${ }^{19}$ In practice, however, these concepts had little effect except to hinder temporarily the activities of labor unions. ${ }^{20}$ Actions in contract were affected only if the restraint was "unreasonable" in the eyes of the court-a very rare event, since private interests were felt to coincide with the public interest..21 The chances of winning in tort, moreover, became extremely limited because of the doctrine that the restraint must spring from malice rather than business motives. ${ }^{22}$ The inadequacy of these

17. See Maxwezl-Fyfe, Monopoly 17-20, 54 (Conservative Political Centre, 1948); Yelverton \& Terborgh, Technological Stagnation in Great Britain (1948). For studies of particular industries, see, e.g., Cinenatograph Filas Council, Tendencres to Monopoly in the Cinematograph Finm Industry (Board of Trade, 1944); REpORT BY the Conantrtee on CEMENT Costs (Ministry of Works, 1947); Repout of tuk: Committe of Enguiry, The Distribution of Butrding Materuals and Conponents (Ministry of Works, 1948).

The extent of the trend towards monopolization is exemplified in the powerful Feder ation of British Industries, an English cousin to the National Association of Manufacturers, which has been accused of advocating "a complete cartelization of domestic industry and international trade." See Stocking \& Watkins, Carrels on Comreticion? 357-9 (1948), citing Federation pamphlets published in 1944. The Federation specifically included in a 1935 list of fields for "cooperation in the commercial and economic sphere through voluntary association" such items as the following: avoidance of "undue" competition, price regulation, interchange of statistical and technical information, publicity and propaganda, centralization and control of sales, and demarcation of sales territories. Brady, Business as a SySten of Power 161-2 (1943). In 1925, eight years after its birth, the Federation claimed affiliation with some 20,000 manufacturing firms with a capital of nearly $\$ 30,000,000,000$. Membership has increased since then. Id. at 165. For a complete picture of the Federation in contrast to the American National Association of Manufacturers, see id. at 153-220.

18. E.g., Hilton v. Eckersley, 6 E. \& B. 47, 119 Eng. Rep. 781 (Ex. 1855); cf. North Western Salt Co. v. Electrolytic Alkali Co., [1914] A.C. 461 (agreement to regulate supply and maintain price level held enforceable).

19. Cf. Mogul Steamship Co. v. McGregor, [1892] A.C. 25. See Saldond, Tonts $\$ 156$ (8th ed. 1934); WrNFIELD, TORTS $\$ 128$ (3d ed. 1946).

20. See Quinn v. Leathem, [1901] A.C. 495; Temperton v. Russell, [1893] 1 Q.B. 435; Friedman, The Harris Tweed Case and Freedom of Trade, 6 Mod. L. REv. 1, 7 (1942).

21. "Their Lordships are not aware of any case in which a restraint, though reasonable in the interests of the parties, has been held unenforceable because it involved some injury to the public." Attorney-General of Australia v. Adelaide Steamship Co, [1913] A.C. 781, 795. See REport of Committee on Restraint of TrAde 5-6 (1931); Lewis, Monopoly and the Law-An Economist's Reflections on the Crofter Case, 6 Mop. L. REv. 97, 101 (1943).

22. See Sorrell v. Smith, [1925] A.C. 700, 712. The malice required was the "disinterested malice" described by Judge Cardozo in Nann va Raimist, 255 N.Y. 307, 319, 
doctrines as a weapon against trade combinations is obvious, and was recognized. ${ }^{23}$ But no changes were made because none were desired; freedom of contract was balanced against the evils of restrictivism in the scales of British policy, and the former was found the heavier. ${ }^{24}$

This attitude, plus deep concern over commercial well-being, led to a general tendency of the government to aid combination rather than to impede it. With the notable exception of the 1919 Committee on Trusts, parliamentary investigation and recommendation was principally concerned with assistance to industrial self-government. ${ }^{50}$ Legislative help in

174 N.E. 690,695 (1931). See Friedman, supra note 20, at 3. The usefulness of the tort rationale was further limited by the requirement of a conspiracy, i.c., two or more persons plotting together. It has been pointed out that this means that the joint action of two unemployed persons can be considered a criminal conspiracy, whereas no action on the part of one corporation, even though it controls the entire output of steel, can be so considered. Friedman, supra note 20, at 3 . This difficulty has been transferred into America in the language of $\$ 1$ of the Sherman Act. 26 STAr. 209 (1890), as amended, 15 U.S.C. $\$ 1$ (1946). But it has been circumvented by the legal concept that a corporation can conspire with itself. See, e.g., United States v. Yellow Cab Co., 332 U.S. 218 (1947) ; United States v. General Miotors Corp., 121 F.2d 376 (7th Cir. 1941), ccrt. denied, 314 U.S. 618 (1941).

23. Lord Bowen, for example, stated around 1890 that "[i]f peaceable and honest combinations of capital for purposes of trade competition are to be strucls at, it must, I think, be by legislation, for I do not see that they are under the ban of the common law." Quoted in Report of Coumitrtee on Restratnt of Trade 6 (1931).

24. See, e.g., Report of Cosamttee on RestratNT OF TRADE 23 (1931).

25. Report of Conantrtee on Trusts (Carp. No. 9236, 1919). The Committee made a detailed study of the industrial practices of the time, and recommended establishment of a Trade and Combinations Department in the Board of Trade. The publicity attendant on their research resulted in the introduction of the Trade and Combines Bill in 1925. See note 9 supra. The Committee's findings and recommendations are collected and discussed in ReEs, Trusts IN BRITISH INDUSTRY (1922).

The Committee was concerned, however, not with the absence of competition, but with the presence of abuses. Despite its possible advantages, competition as such was felt to be wasteful, almost immoral, whereas the potential good in combination was great. See Hurton, supra note 15, at 16; cf. page 905 infra. Proposals for legislation, therefore, centered about the need for safeguards, rather than the desirability of forcins competition on industry. See Rees, Trusts in Britise Industay 250-5, Hilmo:, op. cit. supra note 15 , at $28-30$.

A concurring opinion by four Committee members, including Ernest Bevin and Sydney Webb, emphasizes the lack of faith in traditional "competition." After criticizing the Committee's majority report for not adequately expressing the gravity of the situation, the concurrence went on to say:

"We do not suggest that any action should be taken to prevent or obstruct combination or association in capitalist enterprise. Apart from the experience that no such interference can be made effective, we have to recognize that association and combination in production and distribution are steps in the greater efficiency, the increased economy, and the better organization of industry. We regard this evolution as both inevitable and desirable." Addenduas to Report of the Coarattree on Trusts (Cam. No. 9236, 1919), reprinted as Appendix IV in IEYy, op. cit. supra note 11, at 345.

26. See, e.g., Final Repozt of the Cominttee on Industry asd Trade 297-311 
restraining "disruptive competition" commenced with the Licensing (Consolidation) Act of 1910,27 and was continued by successive governments in the principal sectors of the economy-foodstuffs, mining and metals, fishing, transportation, and textiles. ${ }^{23}$ At no time was there any flare of either popular or governmental resentment against the power of business combinations; British policy varied little, and what variance there was, was between hands-off and active assistance, not between attempts at control and absence of action.

The passage of the Monopolies Act indicates no sudden reversal of past policy. The Act is not designed to cure anything but undesirable symptoms. Both the doctor and the patient like the disease. ${ }^{29}$ The purpose is to control, not to 'destroy, industrial combination; to direct, not to emasculate, the policies of restrictivism. Until nationalization is completed, and the entire means of production are in the hands of the government, something must be done with those sectors of industry which remain in the hands of private enterprise. 30 'The Monopolies Act is that something. Its target is not monopoly as such, for atomization of industry in the name of competition would only impede the march towards nationalization. Rather, in the eyes of both Conservatives and Laborites, the Act is to serve as a means of regulating those practices of monopoly groups which interfere with the current program of full production. ${ }^{31}$ Under it, monopolism will flourish as before, and only the direction of its policy will be changed. Instead of talking freedom of contract and free enterprise while fostering monopolism, the Labour Government has combined theory and practice.

Thus passage of antitrust legislation by a Government committed to total monopoly, in a nation long used to a restrictivist, cartelized economy, is not the paradox it might seem. A prominent Conservative spokesman had outlined, prior to any legislative action on the present Act, a plan remarkably similar to that finally enacted. His program, too, was designed not to destroy industrial combination, but to direct its policies, principally by informal publicity, but if necessary also by regulative measures-price-fixing,

(Card. No. 3282, 1929). "The keys to the new order are not compctition, industrial acquisitiveness, or self-seeking, but co-ordination, science, and service." Id. at 304.

27. 10 EDw. 7 and 1 GEo. 5, 1910, c. 24, restricting freedom of entry into the retail liquor trade. See MAXweld-FyFe, Movoposy 30 (Conservative Political Centre, 1948). Cf. N.Y. Alc. BEv. Law $\$ 17$.

28. For a brief description of this development, with citation of leading legislation, see Maxwell-Fyre, Monopoly 30-3 (Conservative Political Centre, 1948).

29. See Offensive Against Monopoly, 154 Economist 574 (1948).

30. See note 3 supra; Speech of Fernyhough, 449 H.C. DEs. 2072-7 (5th ser. 1948).

31. This purpose was mentioned frequently in the House of Commons debates. Sce, e.g., Speech of Wilson, 452 H.C. DEB. 2163-4 (Labour, President of Board of Trade); Speech of Fletcher, 449 id. 2053-4 (Labour); Speech of Maxwell-Fyfe, 449 id. 2052 (Conservative) (5th ser. 1948). Cf. The Grotind Roots of Monopoly, 155 Economist 619 (1948). 
allocation of raw materials, and special legislation. ${ }^{32}$ And the Labour position is even more explicit. Distrust of competition, and the limits of the theory behind the Act have been clearly and officially stated:

"The Labour Movement . . . is convinced that competitive private enterprise, without public intervention in one form or another, inevitably produces an unhealthy economy and an inequitable distribution of economic and political power. In advocating public supervision of monopoly, the Movement's object is not the restoration of free competition, but the operation of privately-owned industries in what may be broadly defined as the public interest. . . . This object rules out the most clear-cut form of action against trusts and cartels - the outright prohibition of all monopolistic practices by law. For while such legislation might restore free competition, this in itself cannot necessarily be equated with the public interest." 83

\section{The ScOpe of THE ACT}

To implement this policy, the Labour Government, with Conservative support, has drafted an act which in so far as possible talks in terms of economic results rather than business methods. The Act divides the economy into three sectors: supply, processing, and exporting. ${ }^{\text {st }}$ In the field of the export trade, it may be used to direct the policies of any person producing one-third of any type of goods exported from the United IKingdom "both generally and to each market taken separately," and to supervise any arrangements preventing or restricting competition in the export of one-third

32. Maxwell-Fyfe, MLonopoly 49-53 (Conservative Political Centre, 1948). The proposals admitted the need of entirely separate legislation to deal with any restrictive labor practices. Id. at 49. Since Sir David himself-the chief Conservative spolsesman in the Parliamentary debates-proposed that the Mfonopolies Commission's power be e:tended to include investigation of the activities of the boards controlling nationalized industries, an amendment to that effect is possible should control of the Government change hands. See 452 H.C. DEB. 2090-2107 (5th ser. 1948). A shift in politioal control would in other ways tend to lessen, rather than increase, the efficacy of the Act Any antimonopoly policy on the part of the Conservative Party is apt to be weakened by the presence of monopolists within its ranks. See, e.g., 449 H.C. DEB. 2052-9, 2110-22, and 2123-4 (5th ser. 1948).

33. Jonnt Comomittee of the Iaeour Party and the Tendes Union Coitgress on Trusts and Cartels, The Public Control of Mlonopoly 1 (1947).

The practical limits of what cart be accomplished by a few men on a small budget may abrogate success in performing even a limited policing function. No ten-man Commission can be expected to take on the task of clearing up "the legacy of half a century of restrictivism, ignored, condoned or actively encouraged by successive Governments of every party complexion." 156 Economist 95 (1949). Expenses are not expected to run over $£ 50,000$ annually. See 450 H.C. DEB. 563-6 (5th ser. 1948). Cf. the remarlss about the "big act little stick" policy in America in Hasrmion \& THL, Anmmost Is Action 23-6 (TNEC Mionograph 16, 1940).

34. Monopolies Act $\$ 2$. 
of any type of goods from the United Kingdom, or in the supply of the same fraction to any particular foreign market. ${ }^{35}$ And in the supply and processing sectors, the Monopolies Commission may move against:

(1) Any one business organization, or two or more interrelated organizations, which dominate one-third of any particular type of business in the United Kingdom or any substantial part thereof. ${ }^{36}$

(2) Any two or more business organizations, not interrelated, which dominate one-third of any particular type of business in the United Kingdom or any substantial part thereof, and which, whether voluntarily or not, and whether by agreement or not, so conduct their affairs as to "prevent or restrict" competition in that business. ${ }^{37}$

(3) Any arrangements as a result of which something is not made or not done in the United Kingdom or any substantial part thereof. ${ }^{38}$

The words used to formulate this general scope are broad, chosen to enable the Commission to act freely. ${ }^{39}$ But general words can generate prob-

35. Monopolies Act §5. The specific application of the Act to the export trado springs from a fear of the effect of domestic monopoly on Britain's foreign trade position. See Speech of Wilson, 449 H.C. DEB. 2021 (5th ser. 1948); cf. United States V. United States Steel Corp., 251 U.S. 417, 453-4 (1920); Webb Export Trade Act, 40 SтAT. 516 (1918), 15 U.S.C. $\$ \$ 61-5$ (1946). Moreover, at least one purpose of the Act is to enable Britain to fulfill her obligations under the International Trade Organization agreement. See Speech of Wilson, 449 H.C. DEB. 2034-5 (5th ser. 1948) ; Plant, supra note 1 , at $4-6$.

36. Monopolies Act $\S 3(1)$ a, $4(1)$ a. The Conservatives moved an amendment to change one-third to read one-half. The argument was that the clause was too broad, since, coupled with the phrase "or any substantial part thercof," it could be interpreted to mean, for example, that there could be three monopolies in Rutlandshire. The Labour speaker opposed the amendment, calling the ciause as written comparable to American practice. 452 H.C. DEB. 2107-8 (5th ser. 1948); cf. United States v. Aluminum Co. of America, 148 F.2d 416, 424 (2d Cir. 1945) (thirty-three per cent control "ccrtainly" not a monopoly). The amendment was defeated. 452 H.C. Des. 2110 (5th ser. 1948).

37. Monopolies Act $\S \S 3(2), 4(2)$. The phraseology is designed to cover situations where there is no actual arrangement between the persons or firms concerned. This has been said to hit price leadership specifically. Speech of Wilson, 449 H.C. DED. 2033 (5th ser. 1948) ; cf. United States v. United States Steel Corp., 251 U.S. 417 (1920). The American laws have been interpreted to come close to the same position. E.g., FTC v. Ccment Institute, 333 U.S. 683 (1948); American Tobacco Co. v. United States, 328 U.S. 781 (1946). See Rostow, Monopoly Under the Shernan Act: Power or Purpose?, 43 IrL. L. Rev. 745, 778-85 (1949); Comment, Price Systems and Competition: The BasingPoint Issues, 58 YALE L.J. 426, 448, n.94 (1949).

38. Monopolies Act $\$ 3(1) b, 4(1)$ b. The omission of the one-third criterion in this connection further emphasizes the intent to strike down production restrictions and other forms of "private unentreprise." See note 31 supra.

39. Labor practices generally are excluded from the scope of the Act. Monopolies Act $\S \S 3-5$. The exclusion was put on the grounds that labor is not the same thing as a commodity, and that hence any restrictive practices in the field of labor must bo dealt with by separate legislation. Speech of Wilson, 449 H.C. DED. 2038-9; speech of Morrison, 449 id. 2127 (5th ser. 1948) ; cf. 38 STaT. 731 (1914), 15 U.S.C. \& 17 (1941) (Clay- 
lems in specific cases. The word "goods" is used frequently, because some word had to be used to refer to the things that a business produces. It specifically includes buildings and structures, ships and aircraft. ${ }^{13}$ Beyond that, the Board of Trade and the Monopolies Commission can and must adjust their definitions to the conditions of the industry concerned. ${ }^{41}$ Questions as to what competes with what, or whether a certain metal in one state of processing is the same type of goods as that metal in another phase of production, will arise to plague the British Commission as they have arisen to plague the American courts. ${ }^{42}$ The "one-third" criterion is therefore less definite than it sounds: in the determination of its application, the problem of one-third of what, in how substantial a part of the United Kingdom, is left open for application of "such criterion . . . or such combination of criteria as may appear . . . to be most suitable in all the circumstances." 43

And there will be further problems with words. The Act forbids "agreements or arrangements" to be used to prevent new or improved products from reaching the market. ${ }^{44}$ Here the Commission will be forced to decide whether parallel action by competitors, without any evidence of actual oral or written consolidation of policies, sufficiently indicates the existence of an "arrangement." 45 It faces a problem which American courts have not squarely dealt with, ${ }^{46}$ for the results to be looked for are completely negative -the absence of supply, or the non-production of something by British industry, rather than mere curtailment of production. In the last analysis, the problems raised by the wording of the Act will be resolved by emphasis on the economic facts unearthed by investigation, as they bear upon the specific

ton Act). Conservative speakers generally lamented the omission. E.g., 449 H.C. DEn. 2099-2102; 452 id. 2143-4 (5th ser. 1948); cf. MLAXwELL-FyFe, Mfoxopoly 49-50 (1948).

The activities of public monopolies are also outside the scope of the Mfonopolies Commission's investigative powers. Monopolies Act $\$ 2(1)$. This exclusion was attacked by the Opposition, and an amendment was proposed, designed to permit purcly factual reports concerning nationalized industries, etc. 452 H.C. DEs. 2090-2103 (5th ser. 1948). The amendment was defeated. 452 id. 2104.

Both exceptions have received independent criticism. See 154 Ecosiosusr 536; 154 id. $574 ; 154$ id. $705 ; 155$ id. 619 (1948).

40. Monopolies Act $\$ 20(1)$. The same section specifically defines production to include the "getting" of minerals and other substances, and the "taking" of animals and fish. "Supply" is made to include supply by means of lease or hire, and the construction of buildings for another. Ibid.

41. Monopolies Act $\$ 20(4)$.

42. Cf., e.g., United States v. Aluminum Co. of America, 148 F.2d 416, 424-5 (2d Cir. 1945).

43. Monopolies Act $\$ 20(3)$.

44. Monopolies Act $\$ \S 3(2), 4(2)$. See note 37 supra.

45. Cf., e.g., FTC v. Cement Institute, 333 U.S. 683 (1948); American Tobscco Co. v. United States, 328 U.S. 781 (1948).

46. See, however, Special Equipment Co. v. Coe, 324 U.S. 370 (1945), especially the dissenting opinion of Justice Douglas, id. at 380-4; Continental Paper Bag Co. v. Eastern Paper Bag Co., 210 U.S. 405 (1908). 
action the Board of Trade may desire to force the industry concerned to take. Thus parallel action by competitors will probably amount to an "arrangement" where the economic result, as determined by the Commission, is one which is in conflict with national policy. This is particularly likely where there is any stifling of innovation by the leaders of an industry-a practice most explicitly proscribed. ${ }^{47}$

The method of interpretation thus called for is completely ad hoc.48 $\mathrm{It}$ depends on prior knowledge of the specific governmental policy to be effected. This is demonstrated most clearly in the problem raised by reference to behavior that "prevents or restricts competition." be taken literally as indicative of legislative intent, for restraints on competition, as such, are not a target of the Act. ${ }^{50}$ The power to tamper with prices has no relevance in England, because the government retains the power to fix prices.51 But, if exercised, the power to exclude competitors - a second familiar indicium of restriction of competition ${ }^{2}$ - tends to lead to "private unentreprise," 53 lower production, supply limitations, etc., all antithetical to the primary program of increasing the national capacity to produce and adding to the total production. ${ }^{54}$ This emphasis on maximizing production is the keystone of the economic arch the Act seeks to erect, through the use of phrases which hark back to free enterprise concepts theoretically repudiated by British policy. Without desiring competition itself, the Government wants to satisfy the national need for one result of competition-business drive for better products and higher output.

It is this theme also that lies behind the Act's unique contribution to antitrust legislation draftsmanship-the concept of "public interest." of If the Commission's investigation discovers practices coming within the ambit of the Act, it may or may not recommend their proscription, de-

47. See notes 31 and 38 supra.

48. The vagueness of the Act was criticized at the Second Reading in the House of Commons; so ad hoc an arrangement was said to place too great powers in the hands of the President of the Board of Trade. Speech of Morris, 449 H.C. DED. 2062-3 (5th ser. 1948). The necessity for flexible criteria in any antitrust legislation was pointed out by Mr. Herbert Morrison. 449 id. 2132-3.

49. Monopolies Act $\S \S 3(2), 4(2), 5(2)(3)$.

50. See page 905 supra; Joint Conmimtee of the Labour Party and tute Thades Union Congress on Trusts and Cartels, The Public Control of Monopoly 1 (1947). This document was released to the Yale LAw Journal by the Research Department of the British Labour Party.

51. Under Prices of Goods Act, $2 \& 3$ Geo. 6, 1939, c. 118. Cf. United States v. Socony-Vacuum Oil Co., 310 U.S. 150 (1940); United States v. Trenton Potteries, 273 U.S. 392 (1927).

52. American Tobacco Co. v. United States, 328 Ù.S. 781 (1946).

53. The term is taken from The Ground Roots of Monopoly, 155 Econonsss 619 (1948).

54. See Economic Survey for 1949 (CMD. No. 7469, 1949), discussed in Warren, The British White Paper: Economic Sturvey for 1949, 64 Poz. Scr. Q. 161 (1949).

55. Monopolies Act $\S 6$. 
pending on the demands of the "public interest." There exists the possibility of a "good monopoly," or of a practice, restrictive on its face, which appears more satisfactory than any feasible alternative. ${ }^{23}$ An industrial combination which encourages productivity is outside the intended scope of enforcement measures, whereas one a prey to "private unentreprise" is a priority target. But the same methods of control may characterize each combination. The "public interest" concept is formulated to differentiate between them, and is broadly defined as including the overall economic position of the United Kingdom. ${ }^{57}$ More specifically, but not exclusively, the Commission is to consider whether the practices of the industry achieve: (1) efficiency and economy of the means of production, treatment and distribution of goods; (2) an organization designed to increase efficiency; (3) the "fullest use and best distribution of men, materials and industrial capacity"; and (4) the development of new techniques and new markets. ${ }^{.9}$

In skeleton form, therefore, the Commission is to make findings of fact, and then to compare those facts first with the statutory pattern of the basic "one-third control" and other criteria, and second with the "public interest" concept. There will, of course, be some overlapping of these steps in practice. But often the additional and separate "public interest" criterion -necessary for application of sanctions-will put a specific problem in a considerably different light. In the recent Slandard Oil of Califormia case,to for example, the United States Supreme Court upheld an injunction against exclusive dealing contracts between Standard and some 7000 service station operators. Since in the specific factual context the existence of exclusive dealerships was found likely to injure competition in violation of the Clayton Act, ${ }^{60}$ the Court felt constrained to uphold the district court injunction despite the fact that such an injunction might merely lead Standard to buy out, or make agents of its dealers. ${ }^{61}$ Under the British Act, a different final result would be at least probable. Exclusive dealing contracts by one con-

56. "It is less the fact of monopoly that has to be proceeded against than certain effects of monopolistic practices on national economic conditions." Jonst Covantrez op the Labour Party and tee Trades Union Congress on Trusts and Cartzis, Tre Public Control of Monopoly 2 (1947).

57. Monopolies Act $\$ 14$. The term was originally not defined at all. 449 H.C. DEB. 2035-6 (5th ser. 1948). Conservative proposals for criteria closely approximated what the Labour Party wanted. See $449 \mathrm{id}$. 2049-50. The present definition was agreed upon by a Standing Committee and introduced, without objection, at the third reading.

58. Ibid.

59. Standard Oil Co. of California v. United States, 337 U.S. 293 (1949).

60. 38 Stat. 730 (1914), 15 U.S.C. \$§ 12 et seq. (1941).

61. See Standard Oil Co. of California v. United States, 337 U.S. 293, 310; id. at 319-20 (1949) (dissenting opinion); cf. United States v. Columbia Steel Co., 334 U.S. 495, $534-7$ (1948) (dissenting opinion); Appalachian Coals, Inc. v. United States, 283 U.S. 344, 376 (1933) ; Comment, Refusals to Sell and Public Control of Compclition, 58 YALE L.J. 1121 (1949). The majority felt itself bound in particular by its decision in United States v. International Salt Co., 332 U.S. 392 (1947). 
cern controlling over one-third of a substantial market would automatically fall under the primary scope of the Act.62 Further appraisal, however, of the effect of those conditions on the "public interest" would involve consideration of whether Standard's system of distribution was economically efficient, whether it tended to encourage inertia in the industry, and what the effects of an injunction would be. The answers to these questions, which are outside the judicial function of the American courts, ${ }^{63}$ would be ultimately determinative of government action.

In a sense, the public interest concept thus is, and was intended to be, a statutory enactment of the American "rule of reason." 04 But there is a definite difference in emphasis. Under the original American rule, the reasonableness of the disputed action was weighed principally in the light of normal and gentlemanly business methods. ${ }^{65}$ The Monopolies Act switches the standard from what is "normal" to what the contemporary government wants in terms of economic results. ${ }^{66}$ For this reason, the Amer-

62. Monopolies Act §3(1)a.

63. At least according to the majority in Standard Oil Co. of California v. United States, 337 U.S. 293 (1949). See id. at 311 n.14. Cf. Zlinkoff, Monopoly vcrstis Competition-Significant Trends in Patent, Anti-Trust, Trademark, and Unfair Compatition Suits, 53 Yale L.J. 514, 516 (1944).

64. The American rule was formulated by Chief Justice White in Standard Oil Co. of New Jersey v. United States, 221 U.S. 1 (1911). See United States v. American Tobacco Co., 221 U.S. 106, 179 (1911).

65. As originally put forth, the rule purported to carry the common law from which the language of the Act came over into the intent and thrust of the Act. Sce Standard Oil Co. of New Jersey v. United States, 221 U.S. 1, 50-62 (1911); United States v. American Tobacco Co., 221 U.S. 106, 179 (1911). For an expression of doubt that Chicf Justice White correctly interpreted the common law, see HANDLER, A STUdY OF THE CONSTRUCtion AND ENForCEMENT of the FEderal ANTItrust Laws 7-8 (TNEC Monograph $38,1940)$. For an example of emphasis on the normality of growth, campare United States v. United States Steel Corp., 251 U.S. 417 (1920), with Standard Oil Co. of New Jersey, 221 U.S. 1 (1911); see Standard Oil Co. of California v. United States, 337 U.S. 293, 316-7 (1949) (dissenting opinion); United States v. Eastman Kodak Co., 226 Fcd. 62, 79 (W.D.N.Y. 1915), appeal dismissed, 255 U.S. 578 (1921). But the method of growth is no longer relevant when monopoly power is found. See Standard Oil Co. of California v. United States, 337 U.S. 293 (1949) (exclusive dealerships); United States v. Paramount Pictures, 334 U.S. 131 (1948); United States v. Griffith Amusement Co., 334 U.S. 100 (1948); United States v. Socony-Vacuum Oil Co., 310 U.S. 150 (1940) (price fixing). See Rostow, Monopoly Under the Sherman Act: Pozver or Purpose?, 43 ILL. L. REv. 745, 750-63 (1949).

66. Economic necessity is no excuse under American law. E.g., Fashion Originators' Guild of America v. FTC, 312 U.S. 457 (1941) ; United States v. Corn Products Refining Co., 234 Fed. 964 (S.D:N.Y. 1916), appeal dismissed, 249 U.S. 621 (1919). But cf. Appalachian Coals v. United States, 288 U.S. 344 (1933). Nor is improved efficiency resulting from the illegal acts. See United States v. Great Lakes Towing Co., 208 Fed. 733, 744 (N.D. Ohio 1913).

- At least some British legislators failed to see any difference between the American and British approaches. See 449 H.C. Deb. 2047 (5th ser. 1948) (to the effect that under the American rule of reason, the court is able to decide whether a monopoly is 
ican concept of illegality per se could not be applied to conditions simply because they are antithetical to competition. ${ }^{\top}$ If price-fixing arrangements were under consideration in Britain, for example, the reasonableness of the price would be relevant to the problem of sanctions, even if irrelevant to the question of the applicability of the Act. ${ }^{e s}$ What is one issue under the American acts becomes two under the British. The "reasonableness" of a restriction is there a question of the "public interest" of the moment. Further, the fossilizing effect of stare decisis has been abrogated. The legal weight of the language of decisions dealing with parallel practices but different industries, and hence differing economic factors, has been lifted. ${ }^{\text {(3 }}$ The emphasis is on antitrust legislation as a flexible instrument of current economic policy.

\section{PROCEDURE UNDER THE ACT}

This theory of draftsmanship-to coordinate the activities of the Monopolies Commission with those of the national planners-is further evident in the machinery through which the Act will work. The burden of factfinding and recommendation has been shifted from the judiciary, which is felt unqualified for the job, ${ }^{70}$ to a policy-minded administrative body, experts on the problems of monopoly. And that body-the Monopolies and Restrictive Practices Commission ${ }^{71}$-is much under the thumb of the Board of Trade, itself an instrument of central planning for commerce and industry. Thus the Commission may be expected to sit as an arm of the planning authority rather than as an independent enforcement agency.

The difference appears from the very beginning of proceedings under the

good or bad). Cf. Standard Oil Co. of California v. United States, 337 U.S. 293, 311 n.14 (1949).

67. Cf. United States v. Socony-Vacuum Oil Co., 310 U.S. 150, 221-4 (1940).

68. Cf. United States v. Trenton Potteries, 273 U.S. 392 (1927).

69. Cf. Standard Oil Co. of California v. United States, 337 U.S. 293, 304-7 (1949).

70. "The kind of control needed to deal with this general situation is not so much judicial as administrative. ... [The] effects [of monopoly] must be judged by reference to considerations of the most efficient use of resources, the optimum level of output, the stabilization of prices, etc., which are complex problems of economic policy not susceptible to solution by ethical judgments. What is required, therefore, is a flexible administrative control. ..." Joint Coarartitee of the Labour Party aNd the Trades Uinio: Congress on Trusts and Cartels, The Public Control of Mfonopoly 2 (1947).

71. Monopolies Act $\$ 1$. The Commission was christened at the Third Reading. 452 H.C. DEB. 2166 (5th ser. 1948). See note 1 supra. Mfembership may vary from one to ten. Term of office may vary depending from three to seven years, as specified by The Board of Trade at the time of each appointment. The present membership consists of: Sir Archibald Carter, C. N. Gallie, Frederick Grant, Mrs. Joan Robinson, Sir Harold Saunders, Gordon Stott, The Hon. Josiah Wedgwood, and R. E. Yeabsley. Communication from British Information Services to the YaLE LAw Jourasa, dated Oct. 24, 1949, in Yale Law Library. The Econosist remarked in regard to this list, that, "[t] the team may prove, as a team, more effective than the sum of its members. . . But the omens are not good." 156 Ecovosirst 95 (1949). 
Act, for the power to start the machinery in motion rests not in a law enforcement agency but in the Board of Trade. ${ }^{72}$ Acting on its own initiative, or on basis of complaints received, ${ }^{73}$ the Board sends a "reference" to the Commission specifying the facts it is to investigate. ${ }^{74}$ Depending on the circumstances, references are framed either to limit the Commission's duties to investigation and report on the facts, or, at the discretion of the Board, also to require recommendations for government action if the Commission finds that "the conditions in question . . . operate or may be expected to operate against the public interest." 75 In addition, the Commission may be required, at the request of the Board, to submit generalized reports on specific practices. ${ }^{76}$

Provisions concerning the conduct of Commission hearings emphasize the expedition of proceedings rather than the traditional protection of the investigated. Subpoena powers are granted, along with concurrent power to require production of documentary evidence relating to either past activity or estimated future returns. ${ }^{77}$ Right to cross-examination, however, is specifically abrogated. ${ }^{78}$ The right to be heard is dependent on the Commission's interpretation of what is "reasonably necessary" or "practicable." 79 Calling of witnesses on behalf of the business in question is not mentioned. With the exception of the attorney-client privilege, ${ }^{80}$ furthermore, rules of evidence and trial procedure presumably will not be followed;

72. Monopolies Act $\S 2$. See 449 H.C. DEB. 2029 (5th ser. 1948).

73. Complaints received from certain groups must receive public acknowledgement in the annual report of the Board of Trade, even if no reference is made to the Commission. Monopolies Act $\$ 16(3)$. Specifically these groups are consumer groups, trade associations, industrial groups, agricultural groups, local governments, professional associations, and organized labor. Ibid. The last refers only to the T.U.C. The clause will not apply if the Board feels there are "no substantial grounds" for the complaint. Ibid.

74. Monopolies Act $\$ 6$.

75. Ibid. The Commission is concerned with the desirability and form of remedy in the latter case only. $I d . \$ 7(2)$. A reference may be changed at any time, provided that a request for a decision on the "public interest" question may not be withdrawn. $I d$. $\S 6(4)$.

76. Monopolies Act $\S 15$. This can be done only if the practices as utilized by particular industries have been previously dealt with by the Commission. Ibid. Sce 452 H.C. DEB. 2029-45 (5th ser. 1948).

77. Monopolies Act $\S 8(3)$. In America, the Federal Trade Commission has been granted similar powers. 38 STAт. 721 (1914), 15 U.S.C. $\$ \S 46,49$ (1941) (Federal Trade Commission Act). For a description of the difficulties of building a case for judicial action, see HAMrIITON \& TILL, op. cit. supra note 12, at 45-57.

78. Monopolies Act $\S 8(1)$. The Commission has, of course, the power to permit cross-ex:amination. Ibid.

79. Ibid. The right is limited to those who are substantially interested in the specific investigation. That there is any such right at all is the result of a Conservative amendment proposal. Both major parties supported the nonlegalistic approach in gencral. Sec 452 H.C. DEB. 2113-7 (5th ser. 1948).

80. This privilege is specifically retained in Monopolies Act $\$ 8(5)$. 
the Commission is empowered to create its own procedure subject to the direction of the Board of Trade. ${ }^{81}$

There is no provision for judicial review. 82 Normally, reports of the Commission are to be channeled through the Board of Trade to the House of Commons. If the report was limited to a finding of the facts, however, the Board may at its discretion pigeonhole it. ${ }^{83}$ Even if the report includes a decision on the issue of the "public interest," the Board may within certain limits suppress it in whole or in part. ${ }^{84}$ And the Commission's recommendations need never be followed. Opportunity for Parliamentary reversal of the executive decisions thus occurs when both the Commission and the Board consider formal action necessary, 85 but it will probably not be much exercised in practice. So long as the party in power has a workable majority, the strictness of party-line voting and the great quantity of Parliamentary work make it unlikely that recommendations of the President of the Board of Trade will be thoroughly investigated, much less seriously contested. ${ }^{\text {IJ }}$

Furthermore, the Labour Government apparently intends to make frequent use of sanctions not requiring Parliamentary approval. 87 Publicity

81. Monopolies Act $\$ 8(1)(6)$. The Board in turn is responsible to Parliament, to whom it must report procedural directions given the Commission. Id. $\$ 8(7)$.

82. Judicial review was simply termed "undesirable" in the preliminary report. Jonnt Commitiee of the Labour Party and the Trades Union Congress on Trusts and Cartels, The Public Control of Mlonopoly 6 (1947). Its absence gave rise to no opposition. This is in line with the Act's abrogation of the concept of adversary proceedings, and its treatment of the problem of monopoly as a purely economic, sather than legal, question. See note 70'supra.

83. Monopolies Act $\$ 9$.

84. Ibid. In order to withhold the whole or part of any report not limited to a finding of the facts, the Board must find that disclosure of the content of the report will do injury to either the public interest, or, because of the existence of secret processes, etc., to the legitimate business interests of the parties concerned. Interpretation of the first exception is left up to the Board without limitations. "Legitimate business interests," however, will be protected only if that can be done without affecting the "sense, elarity or cogency" of the report. Ibid. Cf. American Sumatra Tobacco Corp., 7 S.E.C. 1033 (1939), aff'd, 110 F.2d 117 (D.C. Cir. 1940).

85. Mnonopolies Act $\S 10(1)$. There is a loophole in this whereby action can be initiated, by Parliament resolution, although the Commission reported the practices under investigation as not operating against public interest. Ibid. Since this exception was defended in Parliamentary debates by Board of Trade officials asainst Conservative attacks, it seems likely that it is intended to operate as preservation of the executive, rather than legislative, power of veto over the conclusions of the Commission. See 452 H.C. DEB. 2117-31 (5th ser. 1948). The Labour spokesman contended that the exception would rarely be used, but was necessary in view of the vagueness of the "public interest" concept. 452 id. 2121-3.

86. See 452 H.C. DEB. 2122 (5th ser. 1948) (use of Whips if going is hard); Off crsive Against Monopoly, 154 Ecovourst 574, 575 (1948) (safeguard of Parliamentary approval weakened by congestion of business and rigor of party discipline). Cf. Mfeier, supra note 4 , at 336 .

87. See, e.g., 449 H.C. DEB. 2035 (5th ser. 1948) ; Cohen, supra note 5, at 487. 
and extra-legal recommendations can force the industry concerned to take the desired action. The British Government holds powerful weapons in price control, allocation of scarce materials, land-use legislation, and the threat of nationalization of government subsidized competition. ${ }^{8 s}$ Backed by the weight of such power, semi-official advice from the Board to a group of business men is persuasive. If the advice is formally included in a Commission report, further references may be made to ascertain whether the recommendations are in fact being followed. ${ }^{89}$ From the Government side, this method of non-binding sanctions, inducing "voluntary" action by the business concerned, has much to recommend it. By avoiding court action and parliamentary debate, the Government gains speed and flexibility in carrying out desired changes, as well as means of continuing supervision. And from the business side, there is little to be gained by holding out for formal sanctions. The chances of prevailing before Parliament are negligible, and the imposition of formal sanctions only further restricts freedom of decision.

Formal sanctions, mainly for use against recalcitrant or particularly longsinning groups, ${ }^{90}$ are provided in authority given for the issuance of ministerial orders. Procedurally, the order must be based on a parliamentary resolution, following receipt by the House of Commons of a Commission report.91 In practice, it will be written by the President of the Board of

88. See Prices of Goods Act, 2 \& 3 GEo. 6, 1939, c. 118 (price control); Goods and Services (Price Control) Act, 4 \& 5 Geo. 6, 1941, c. 31 (price control); Town and Country Planning Act, 10 \& $11 \mathrm{Gzo} .6,1947$, c. 51 (land use allocation). Rationing regulations are made under Emergency Powers (Defence) Act, 2 \& 3 GEo. 6, 1939, c. 62, and Emergency Powers (Defence) Act, $3 \& 4$ Gro. 6, 1940, c. 20. Sce also Industrial Organization and Development Act, 10 \& 11 Geo. 6, 1947, c. 40 (setting up local development councils); Borrowing (Control and Guarantees) Act, $9 \& 10$ GEo. 6, 1946, c. 58 .

89. Monopolies Act $\S 12$. This action may be taken also when recommendations have been made by competent authorities. Ibid. See note 92 infra: Recommendations thus made are not backed by any legal sanctions, and may therefore be made even when the Commission's report has been limited to a finding of the facts. In this case, there is, of course, no parliamentary review at all.

90. Publicity is expected normally to provide sufficient reason for a monopolistic group to change its habits. See 449 H.C. DEB. 2035 (5th ser. 1948).

91. Monopolies Act $\$ 10$. There are four prerequisites to such an order: (1) a refertence to the Commission not so framed as to limit the investigation and report to the facts; (2) the laying of the report before Parliament, with or without omissions; (3) a finding by the Commission in its report that the Act is applicable; and (4) either a finding by the Commission that the conditions investigated operate against the public interest, or a resolution to that effect by the House of Commons. The first two limitations provide the Board of Trade with a screening process which can effectively prevent positive action. The latter clause of the last limitation gives it the opportunity of overruling the Commission. See note 85 supra.

Ministerial orders generally are designed to permit legislation by administrative and executive agencies. The process of specifying particular law from the basis of a broad grant of power from the legislature is parallel to the rule-making powers of such American agencies of the Treasury, or the Office of Price Administration. But the British system of orders goes further, and in effect permits generic delegated legistation. For a 
Trade, or the Minister most directly concerned, and then submitted to Parliament for official blessing. The Board of Trade is not the sole director of the British economy, simply the best place in which to locate control of the investigatory and recommendation functions of any administrative body concerned with the activities of British industry in general. At times the Monopolies Commission may be required to look into the practices of an industry falling within the jurisdiction of a Minister other than the President of the Board of Trade. The Act is therefore framed to prevent interdepartmental conflict by permitting the Minister under whose direction the business in question most readily falls to issue the order, and see to its enforcement.92 In any case, no order can be couched in other than language of prohibition-i.e., it cannot command dissolution or divestiture. ${ }^{03}$ But the range of its scope may be broader than, for example, an FTC cease and desist order in America; it may be applicable to specific persons only, or may declare certain practices to be unlawful in general, thus in effect enacting new legislation.94 Enforcement rests in the courts, which must respect a governmental request for an injunction if an order is not obeyed. ${ }^{25}$

specific example under the Monopolies Act, see note 94 infra. The majority of statutory orders, covering rationing, land confiscation, etc, are made under the Emergency Powers (Defense) Act, 2 \& 3 GEo. 6, 1939, c. 62, which is still in force. See, e.g., Revicw of Current Legislation-Great Britain, 29 J. Cosrp. LEG. \& INT't. L. 1 (1947); WaDE \& Phillips, Constitutional Law 241-2, and c. 5 (3d ed. 1946), reviewed in $29 \mathrm{~J}$. Cosp. LEG. \& INT'L I., Parts 3 \& 4, at 63 (1947).

92. Monopolies Act $\$ 10(2)$. In addition to the Board of Trade, the following authorities may issue orders under the Act: Minister of Supply, Minister of Works, Minister of Fuel and Power, Minister of Health, Minister of Agriculture and Fisheries, the Admiralty, Minister of Food, and the Secretary of State. Id. \$20(1).

93. Specifically, authorization is given to forbid any agreements or arrangements, past or prospective, which are considered undesirable, to outlaw boycotts, including refusal to sell (cf. Comment, Refusals to Sell and Public Control of Compclition, 58 YALE L.J. 1121 n.1 (1949)), and to declare unlawful preferential rebates, or other forms of customer preferences, and tying contracts, exclusive dealerships, and the like. IIonopolies Act $\S 10(2)$. The absence of the dissolution and divestiture remedies is to be expected in view of the limited purpose of the Act. See pages 904-5 supro. There will be no "unscrambling of the eggs." Movement against non-use, however, may in effect constitute a form of compulsory licencing.

94. Monopolies Act $\$ 10(3)$. For example, the Electric Lamp Manufacturers' Association has already been referred to the MIonopolies Commission for study. Communication to the Yale Law Journal from the British Information Services, dated October 24, 1949, in Yale Law Library. This "classic of the textbooks" has reportedly gained a monopoly through use of a patent pool, and maintained it through resale price maintainance, sales quotas, and production restrictions. See LEwrs, op. cit. stipra note 3 , at 12; LUCAs, op. cit. supra note 8, at $64 ; 449$ H.C. DEB. 2054-8 (5th ser. 1948). Any Ministerial order made on the basis of the Commission's report may cither require the Association to discontinue, for instance, its sales and production quota systems, or may deelare all such systems, no matter by whom instituted, to be henceforth unlawful.

This method of sanction is close to the American doctrine of illegality per sc. Use made of it, however, will probably be limited, since only the results, never the form, of restrictive practices are the target of the Act. See page 904 supra.

95. See 449 H.C. DEB. 2037 (5th ser. 1948). An injured private party may also ask 
No criminal sanctions are provided. ${ }^{96}$ This divergence from the American scheme reflects the fundamental British moral attitude towards the Monopolies Act. The keynote is cooperation between government and industry to create a productive economy, without regard to the ethical character of monopolistic practices. ${ }^{97}$ A decision adverse to a private concern thus contains no more of an implication of moral turpitude than does a ratefixing order after a hearing by the Federal Power Commission.

This concept of monopoly as a purely economic problem accounts also for the arbitrary procedure and limited opportunity for review embodied in the Act. The manifest lack of "due process" may or may not be as bad as it looks, depending on one's political philosophy. The Labour Government considers itself the instrument of the people in creating social and economic welfare for the nation at large..$^{98}$ In the industrial world, it must control what it does not own. To this end it has established an administrative board of experts on monopoly, charged with implementing and coordinating policy, and free to discuss each case on the level of what are considered to be the only relevant questions--the effects of the conditions under investigation, and the desirability and form of sanction. To its way of thinking, the Government has the power to control completely all aspects of the national economy; that it has chosen to control only partly does not mean that it must run the risk of legalistic confusion of issues, lengthy and expensive judicial proceedings, possible court reversals, and seeping dilution of its economic policies. The need for application of legal standards has thus been kept to a minimum, while the responsibility for making the necessary political-economic decisions has been placed in the hands of personnel trained and free to think in those terms.

for an injunction against further disobedience of an order issued under the Act. Ibid. The court cannot review the findings of the Commission as to the applicability of the Act. Hence, such issues as what is a restraint on competition, or what constitutes one-third control over an industry will not come up unless the order which is alleged to have been violated contains some such language. The validity of the order can be questioned only on constitutional grounds, if the authority issuing the order can be shown to have exceeded the powers granted by the Act. Since the orders will already have parliamentary approval, this possibility is practically non-existent. See Review of Current Legislation, 29 J. CoMrp. LEG. \& INT'L L. 1-2 (1947).

96. Monopolies Act $\$ 18$ provides criminal penalties for anyone convicted of an "offense" under the Act. The sole purpose of this clause is to give teeth to the subpoena and other investigatory powers of the Commission. See $i d . \S 8(3)$.

97. "A monopoly is neither good nor bad in itself, but it has the power to be cither good or bad." Harold Wilson, President of the Board of Trade, at the Second Reading, 449 H.C. DEB. 2021 (5th ser. 1948).

98. A typical statement of the Labour position was made by Clement Attlee during the political campaign of February, 1950: "Labor does not believe that men and women should be required to submit their lives to the indiscriminate play of blind economic forces. It believes that men can control their economic environment and must be free to do so." Quoted in the N.Y. Times, Feb. 19, 1950, $\$ 6$, p. 24. Sce also Wuruars, TuE Triple Chatlenge 99-109 (1948). 


\section{The American Contrast}

The British anti-monopoly program differs from its American counterpart both in substance and procedure. The British attempt is to regulate the policies of monopolized industries rather than to thrust competition upon them, and they start unhampered by a haphazard pyramiding of sometimes conflicting legislation. ${ }^{99}$ Moreover, the regulation is virtually divorced from the courts, and is coordinated on the administrative level with over-all economic policy. American procedures, on the other hand, have depended heavily on the judiciary and have never been systematically meshed into a coherent regulatory scheme. The United States may wish to borrow little from the British economic philosophy. But the history of American attempts to promote competition indicates that the British administrative machinery might prove useful indeed.

In contrast to current English theory, the traditional basis of American antitrust legislation is preservation of the competitive system. ${ }^{1 \mathfrak{H}}$ Competition is the spice of life: theoretically, the automatic mechanism of the competitive market creates both fair prices and the desired distribution of commodities. The need for pleasing the consumer places a premium on lower prices, better products, individual initiative, and increased economy and efficiency in production and distribution. ${ }^{102}$ Beyond this, the theory of competition is tied in with the foundations of a total philosophy. Politically and socially, it is a part of pluralism and democracy, of decentralization of power. It serves to protect a democratically created government against the essentially dictatorial power of industrial giantism. The ramifications of an economic theory are deeply ingrained in the concept of "Americanism." 102

But the theory received hard knocks from the first. The rapid expansion of industrial power in the latter half of the nineteenth century gave rise in

99. Contrast the sixty years' patchwork of American legislation. See pages 918-9 infra.

100. See, e.g., Apex Hosiery v. Leader, 310 U.S. 469, 493 n.15 (1940).

101. See, e.g., Samueison, Econonites-An Introductory Ariaysis 35-S (1948).

102. Distrust of monopoly power is in fact rooted in the thought of the Founding Fathers. Jefferson was in favor of a constitutional restriction on monopolies. Letter to James Madison, dated December 20, 1787, in Troaras Jefrerson, LIFe Axt Selectrod WrITINGs 437 (Modern Library ed., 1944), quoted at the head of Rostow, Mronopoly under the Sherman Act-Power or Purpose?, 43 ILL L. Rev. 745 (1949). But the modern theory of laissez-faire was no part of this distrust. Price-fising and public ownership of business enterprise were common in the first half of the nineteenth century, and were challenged only on practical grounds. The modern concept of an American heritage of freedom from positive government action in the economic sphere was largely a creation of the post-Civil War period. For a case study of the rise of the laissez-faire concept in Pennsylvania, see Hartz, Econosuc Policy and Desroctatic Troughr, passim and especially Part IV, The Myth of Laissez-Faire (1948). 
America to flagrant abuses. The age of the robber barons began. ${ }^{103}$ When it became clear that competition was not self-perpetuating, the Sherman Act was enacted, making it a crime to "monopolize, or attempt to monopolize ... any part of the trade ... between the several States," and declaring all contracts in restraint of trade to be illegal. ${ }^{104}$ Judging from the sweep of the language alone, the intent of the Act, prima facie, seemed clear: to stop the concentration of economic power, and to restore to the economy the protection of free competition. 105 However, despite the "comprehensiveness of the enumerations embodied in both the 1st and $2 d$ sections," Congress had failed to include "any direct prohibition against monopoly in the concrete." 106 A brief flurry of dissolution decrees blew up, swept across certain sectors of the economy, and was dissipated. ${ }^{107}$ After the United States Steel decision in $1920,{ }^{108}$ the Sherman Act became a hazy edition of what the British Act is now, a weapon to restrain abuse rather than to destroy the monopoly power giving rise to the abuse. ${ }^{103}$ And while the Federal Trade Commission Act ${ }^{110}$ and the Clayton Act, ${ }^{111}$ both enacted in 1914, were framed in terms of restoring competition, they actually reached only symptoms. ${ }^{112}$

103. See Josephson, The Robber Barons (1934); Hicks, Higu Finance in tile SEXTIES (1929).

104. 26 STAT. 209 (1890), as amended, 15 U.S.C. $\$ \$ 1-7$ (1946).

105. The language of the Act is almost the only criterion by which intent can be judged. The Act was not a carefully worked out measure, but rather an automatic political response to the strong public sentiment against the trusts of the time. It was passed with only one dissenting vote, after five days' debate, but no hearings whatsocver. See Fatnsod \& Gordon, Government and the AMterican Economy 450-2 (1941); cf. Purdy, Lindaht, \& Carter, Corporate Concentration and Public Policy 302-3 (1942). The legislative history of the Act is given in some detail in WALTER, History OF THE SHERMAN LAW 1-46 (1910).

106. See Standard Oil Co. of New Jersey v. United States, 221 U.S. 1, 62 (1911).

107. In 1911, dissolution decrees were granted in Standard Oil Co. of New Jersey v. United States, 221 U.S. 1 (1911), and United States v. American Tobacco Co., 221 U.S. 106 (1911). See note 133 infra.

108. United States v. United States Steel Corp., 251 U.S. 417 (1920).

109. See Standard Oil Co. of California v. United States, 337 U.S. 293, 315-17 (1949) (dissenting opinion). For the thesis that the legal and economic standards of monopoly were then far apart, see Mason, Monopoly in Laze and Economics, 47 YALE L.J. 34 (1937).

110. 38 Star. 717 (1914), 15 U.S.C. $\$ 41$ et seq. (1946).

111. 38 STAT. 730 (1914), 15 U.S.C. $\$ 12$ et seq. (1946).

112. Both the F.T.C. Act and the Clayton Act were directed against business methods which operated to restrict competition, and hence might lead to monopoly, rather than against the existence of monopoly power. Remedies available to the Commission were therefore restricted to cease and desist orders. See FTC v. Cement Institute, 333 U.S. 683, 693 (1948). The Clayton Act was criticized at its inception by Senator Recd for weakness in language and scope. 51 Cosc. Rec. 15825 (1914); see Kefauver, The Sit preme Court and Congress versus Monopoly, 20 TENN. L. REv. 254, 256 (1948). If the criticism was not valid at the time, it was later justified by judicial emasculation of $\$ 7$, which was directed against growth by merger: See Kefauver, supra, at 264-8; OppEN- 
Subsequent decades witnessed the growth of a fundamentally different philosophy, masquerading under the old symbols. "New competition," a move towards cooperative self-government in the business world, was born in the 1920's. ${ }^{113}$ With the NRA experiment, 114 the term became "fair competition." The Robinson-Patman Act of $1936^{115}$-though passed as a plausible attempt to tighten the Clayton Act's strictures against "price discrimination"--became in application a vehicle for the protection of small competitors rather than of the process of competitive change. The recent Standard Oil Co. of Indiana decision, ${ }^{116}$ for example, in effect enforced retail price maintenance in order to protect independently owned retail gas stations. And the Miller-Tydings Act of 1937 bestowed congressional blessing on state "fair trade" laws, which openly proscribe price competition on the retail level.117 In brief, the spirit of this trend was not the spirit of "competition," but of "live and let live," a policy of insulating powerful distributor groups and tiny distributor satellites alike from competitive unrest.

Subsequent antitrust decisions have tended to reverse this trend. One group of decisions, under Section 1 of the Sherman Act, Section 3 of the Clayton Act, and Section 5 of the Federal Trade Commission Act, have struck vigorously at practices and methods whereby monopoly power is made effective. Now illegal per se, or virtually so, are tie-in sales, group boycotts, and any agreements which affect price. ${ }^{118}$ The scope of monopoly power under a patent has been severely circumscribed: it is doubtiul that patentees can under any but the most limited circumstances fix the prices

HEISS, op. cit. sipra note 6, at 266-7; PURDY, LINDAHL, \& CARTER, op. cir. sipra note 105, at 383-9. This weakness has evoked strong pressure for legislative overruling of the judicial rule. See, e.g., House Comarittee on Sarall Business, Repost on Moosorolistic and UNfatr Trade Practices, H.R Rep. No. 2465, 80th Cong., 2d Sess. 25 (1948).

113. See generally BuRns, The Deczine of Cosmetrtion (1936). For references to other material, see bibliography in id. at 591-604.

114. National Industrial Recovery Act, 48 Srar. 195 (1933), declared unconstitutional in Schechter Poultry Corp. v. United States, 295 U.S. 495 (1935).

115. The Robinson-Patman Act, striking at preferential price rates, was enacted as an amendment to $\S 2$ of the Clayton Act. 49 STAT. 1526 (1936), 15 U.S.C. $\$ 13$ (1946). See page 920 infra.

116. Standard Oil Co. v. FTC, 173 F.2d 210 (7th Cir. 1949), cert. granted, 338 U.S. 865 (1949). See Adelman, Integration and Antitrust Policy, 63 HARv. L. Rev. 27, 60-74 (1949); Note, The Swinging Door-Or How To Obey One Antitrust Law By Violating Another, 59 Y ALE L.J. 158 (1949).

117. The Mfiller-Tydings Act, exempting certain types of resale price maintenance, and thus preventing price wars, was made an amendment to $\$ 1$ of the Sherman Act. 50 STAт. 693 (1937), 15 U.S.C. $\$ 1$ (1946).

118. Tie-in sales: International Salt Co. v. United States, 332 U.S. 392 (1947), 57 YALE L.J. 1298 (1948). Group boycotts: Associated Press v. United States, 326 U.S. 1 (1945); Fashion Originators' Guild of America v. FTC, 312 U.S. 457 (1941). See Comment, Refusals to Sell and Public Control of Competition, 58 YALE L.J. 1121, 1136-40 (1949). Price agreements: FTC v. Cement Institute, 333 U.S. 683 (1948); United States v. Socony-Vacuum Oil Co., 310 U.S. 150 (1940). 
which their licensees may charge. ${ }^{119}$ Moreover, any antitrust law violations connected with the licensing of patents may constitute a defense to a suit by the patentee for infringement or for royalties. ${ }^{20}$

But potentially the most far-reaching group of decisions have been those re-invigorating Section 2 of the Sherman Act. ${ }^{121}$ Where monopoly exists, according to these decisions, the gentlemanliness of policy, or the normality of growth, constitute no excuse. The existence of the power is the violation, no matter how innocently the power is used, unless it was "thrust upon" the industry. ${ }^{122}$ And one implication seems to be, although it is not a necessary one, that the purpose of the Sherman Act is to preserve an atomized economic structure, "to perpetuate . . . for its own sake and in spite of possible cost, an organization of industry in small units" 123-to reconstitute, in short, the "ideal" competitive system as the American system of free enterprise.

\section{The Path of the Future}

To the extent that the "new" Sherman Act decisions identify the existence of small business with the existence of competition, they bring into sharper focus a conflict already institutionalized in the co-existence of the Robinson-Patman and Miller-Tydings Acts with the basic antitrust laws. The size of giant corporations may raise problems which must be dealt with through some form of government action. But the decision must be made whether these problems can best be handled by penalizing competitive success, and protecting "in spite of possible cost" expensive means of production and distribution. Government-sanctioned wholesale and retail price maintenance may aid small business. It does not follow that it therefore is an aid in maintaining effective competition. If competition is to endure as an economic ideal, legal methods of restraining it under a verbal guise of restoring it should be discarded. ${ }^{124}$

119. United States v. United States Gypsum Co., 333 U.S. 364 (1948); United States v. Line Materials Co., 333 U.S. 287 (1948).

120. Mercoid Corp. v. Minneapolis-Honeywell Regulator Co., 320 U.S. 680 (1944); Sola Electric Co. v. Jefferson Electric Co., 317 U.S. 173 (1942).

121. The principal cases are United States v. Paramount Pictures, Inc., 334 U.S. 131 (1948); Schine Chain Theatres v. United States, 334 U.S. 110 (1948); United Statcs v. Griffith Amusement Co., 334 U.S. 100 (1948) ; American Tobacco Co. v. United States, 328 U.S. 781 (1946); United States v. Aluminum Co. of America, 148 F.2d 416 (2d Cir. 1945); cf. United States v. Columbia Steel Co., 334 U.S. 495 (1948).

122. See United States v. Aluminum Co. of America, 148 F.2d 416, 429 (2d Cir. 1945). Judge Hand's language was specifically approved in American Tobacco Co. v. United States, 328 U.S. 781, 813-4 (1946). See Rostow, The Ncw Sherman Act; A Positive Instrument of Progress, 14 U. of CHr. L. Rev. 567, 577-80 (1947).

123. United States v. Aluminum Co. of America, 148 F.2d 416, 429 (2d Cir. 1945).

124. Two recent cases pointing up the conflict are Standard Oil Co. of Indiana v. FTC, 173 F.2d 210 (7th Cir. 1949), cert. granted, 338 U.S. 865 (1949), and United States v. New York Great Atlantic \& Pacific Tea Co., 173 F.2d 79 (7th Cir. 1949). 
The Miller-Tydings and Robinson-Patman Acts aside, the antitrust laws have in some ways been a notable success. The incipierit monopolist has been restrained, both through positive action and the deterrent effect of the threat of action, from widespread use of restrictive practices and unfair methods of competition. The robber barons have been stopped-complete and ruthless control of industry is extinct. ${ }^{125}$ Despite appropriations difficulties-the "big act little stick" shortage "1sa_, there is no lack of energy in attempting to enforce the law. The Antitrust Division of the Department of Justice had, in November 1949, one hundred and twenty-seven cases pending against large concerns. ${ }^{127}$ Moreover, the government will probably get a decision in its favor, if not an effective remedy, in them all; to that extent it wins practically all the actions it brings. ${ }^{123}$ Yet the problem of monopoly in American industry remains pressing. ${ }^{13}$ The alternatives are becoming clearer; if antitrust action cannot counteract the impulse towards concentration of private economic power, at some point that power will be taken from private hands. ${ }^{130}$ It is time for a reappraisal. ${ }^{131}$

References to discussions of the problem are given in Note, The Suringing Door-Or How To Obey One Antitrust Law by Violating Another, 59 YALE L.J. 158 (1949), and Note, Trouble Begins in the "New" Sherman Act: The Perplexing Story of the AEP Case, 58 Y ALE L.J. 969 (1949).

125. The contrast with the English experience of bypassing antitrust law is striling. See Rostow, Monopoly uruder the Sherman Act-Power or Purpose?, 43 Ir工. L. REv. 745, 750 (1949), quoting YeLverTon \& TERBOUGE, op. cit. supro note 17, at 65; Off crsive Against Monopoly, 154 Econosrrst 574, 575 (1948) ("[T]here are few symptoms in America of that acquiescence in restriction, that fear of dynamic change, that conviction that competition is a Bad Thing, which in England characterizes not only monopolistic big business but practically every class of society").

126. The phrase is used in the discussion of the problem of appropriations in Hamilton \& Till, Antitrust in Action 23-6 (TNEC Monograph 16, 1940). See also Amold, Antitrust Lazo Enforcenent, Past and Future, 7 Law and Contesrp. Prod. 5, 9-10 (1940).

127. The cases are listed and summarized in a communication to the YALE LAY Journat from Herbert A. Bergson, Assistant Attorney General, dated Nov. 10, 1949, in Yale Law Library.

128. For statistics prior to 1940 , see Hamilton \& Till, Antilrust in Action 121-40 (TNEC Monograph 16, 1940). See also note 133 infra.

129. For example, the census of manufacturers taken in 1947 shows nineteen major industries to be concentrated to the extent of $85 \%$ or more in four companies or less. N.Y. Times, Dec. 5, 1949, p. 1, col. 5. Such statistics do not show up the tremendous size of companies whose power is spread over more than one industry. For a brealdown of the scope of the activities of E. I. Du Pont de Nemours \& Co., whose sales in 1946 totalled over three-quarters of a billion dollars, see EDwards, Ifaritammic CospremTION 100 n.14 (1949).

The size of American industrial giants tends to evoke statement that monopoly itself is increasing. See, e.g., Callmann, The Essence of Antitrust, 49 CoL. L. REv. 1100 (1949). The evidence seems inconclusive. See discussion and citations in Adelman, Effective Competition and the Antitrtst Laws, 61 HARv. L. REv. 12S9, 1291-7 (1948); Houghton, The Progress of Concentration in Industry, 38 Aur. Ecos. REv. Surp. 72 (1948).

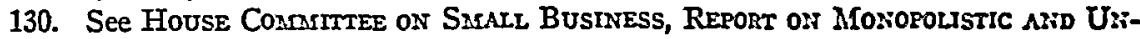
fatr Trade Practices 29-33, H.R. Rep. No. 2465, 80th Cong., 2d Sess. (1948) (effective 
The least exacting policy road lies behind us. It would be possible to turn back to the pre-war path. This is not really as much of a path as a merry-go-round, on which the government rides, slaying an ogre on one trip around only to meet him again, bigger and stronger, albeit politer, on the next. When coupled with successful attacks on collusive restraints of competition and unfair methods of competition, such a policy has the advantage of preventing most abuses, and thus to some degree limiting the

antitrust laws stressed as the only alternative to "authoritarian economic system"); TNEC, Final Report and Recommendations 8-9 (1941) (the alternative to competition is some form of concentrated government authority). A wartime policy statement by the British Labour Party attributed the failure of the capitalist system partially to the ham-stringing of industry by monopolistic combinations. Natronal Executive CoNmittee of Labour Party, Full Employment and Financial Policy 2 (1944). For the thesis that industrial dynamism inevitably leads to giantism and hence to socialism, by a process of "Creative Destruction," see Schumpeter, Capitalisu, Socinusu and DEMOCRACY, passim (1942).

131. The need for a reappraisal has been recognized by the Government. Between 1938 and 1941, the Temporary National Economic Committee launched a detailed amalysis of the concentration of economic power in American industry, and reported their findings in 43 monographs and two reports. For a listing of these, see Oppenuen, op. cit. stipra note 6, at 83-5. The work of the Committee has been termed a failure. Galbraith, Monopoly and the Concentration of Economic Power in Elits, A Sunvey of ContemroRARY ECONOMICs 122-4 (1948). But whether or not the criticism of over-conservatism is valid, the Committee supplied two elements essential to a successful revitalization of the antitrust laws: publicity and a mass of source material.

Since the war, more work has been done. The work of the Congressional Committee on Small Business has resulted in two major reports. STAFF REport to THE MONopoly

Subconmattee of the House Committee on Suali Business, United States versus Economic Concentration and Monopoly (1946); and House Committee on SMall Business, Report on Monopolistic and Unfair Trade Practices, H.R. Rep. No. 2465, 80th Cong., $2 d$ Sess. (1948). The Federal Trade Commission has made a series of reports. E.g., FTC, The Present Trend of Corporate Mergers and Acguisitions (1947). More recently, the problem of monopoly has been under scrutiny by a Subcommittee of the House Judiciary Committee, under the direction of Representative Celler of New York. See N.Y. Times, Nov. 20, 1949, $\$ 4$, p. 7, col. 1-2. Partially as a result of the findings of this committee, the President has directed Secretary of Commerce Sawyer to head a committee to prepare a "positive" approach to the prevention of monopoly. N.Y. Times, Dec. 5, 1949, p. 1, col. 4. What this means is not yet clear.

The danger of government control poses a difficult problem to business men. It is said that they approve of antitrust law enforcement only in theory. See McDonald, Businessmen and the Sherman Act, Fortune, Jan. 1950, p. 104. If this is so, they may be walking into a trap. "Those people, in and out of the halls of government, who encourage the growing restriction of competition .... are shouldering a terrific responsibility. Consciously, or unconsciously, they are working for centralized business and financial control. Consciously, or unconsciously, they are therefore either working for control of the Government itself by business and finance or the other alternative-a growing concentration of public power in the Government to cope with such concentration of private power. The enforcement of free competition is the least regulation business can expect." Public Papers and Addresses of Frankin D. Roosevelt 313 (1938), quoted in Zlinkoff, op. cit. supra note 63 , at. 514 n.1. 
power of the combinations it is helpless to control or destroy. But its result is that competition continues to be more of a myth than a reality, without any decision having been made whether competition in any particular industry is either desirable or possible. Moreover, it leaves concentrated power in the hands of a self-elected and self-perpetuating class of industrial management, and does so by default, not as a result of a conscious policy.

Through the "new" Sherman Act decisions, ${ }^{182}$ the United States Supreme Court has given a more promising answer. But the answer is not complete. A policy decision made in the courts does not entail the broad follow-up action attendant on the voice of the legislature or the executive. Available judicial sanctions may not be capable of making substance of the words in the opinions. ${ }^{133}$ Announcement of a new doctrine by the judiciary does not mean that other branches of the government are prepared to go along with it; a government sale of a strategically located plant to an industrial giant belies the sweep of Supreme Court language. ${ }^{134}$ No judicial doctrine can compel the bringing of the right action at the right time.

Moreover, the economic issues are still in flux. The Court's criteria now go beyond the outward manifestations of restraints on competitioncollusion and abuse - to the economic fact of lack of competition. Yet this

132. The phrase is from Rostow, The New Sherman Act; $A$ Positive Insirument of Progress, 14 U. of CHI. L. REv. 567 (1947). Cf. Galbraith, op. cit. supro note 131, at 118 n.46.

133. In the depression year of 1932, the American Tobacco Company made a net profit of over $\$ 100,000,000$. American Tobacco Co. v. United States, 328 U.S. 781, 806 (1946). The penalty imposed for their monopolization, in one of the leading cases under the "new" Sherman Act, was fines amounting to $\$ 255,000$. Id. at 783. No action has yet been taken under the decision in United States v. Aluminum Co. of America, 148 F.2d 416 (2d Cir. 1945). Control of the market in aluminum is now in the hands of three companies, and it is at least doubtful that any action can be taken. See N.Y. Times, Dee. 5, 1949, p. 33, col. 4; Kefauver, The Suprente Court and Congress z'ersus Monopoly, 20 Tenv. L. Rev. 254, 262-4 (1948); Rostow, Monopoly suder the Shermats Act-Pouter or Purpose?, 43 ILI. L. REv. 845, 780 (1949).

The 1946 decision was the second time the American Tobacco Company was found to be a monopoly. The first time it was dissolved. United States v. American Tobacco Co., 221 U.S. 106 (1911). Mr. Justice Brandeis remarked that the decree was based on a new constitutional prohibition: "What man has illegally joined logelher, let no court put asurder." Brandeis, The Curse of Bigness 103 (1934).

134. The United States Steel Corporation refrained from bidding for the important plant at Geneva, Utah, which was offered by the War Assets Administration, on the grounds that further expansion might violate the antitrust laws. Upon Government urging, backed by the opinion of the Attorney-General that acquisition of the plant would not constitute a Sherman Act violation, the Corporation submitted a bid. The bid was successful. Following their usual pattern of integration, the Corporation then acquired the assets of the Columbia Steel Co. in Oregon. At this point, the Department of Justice commenced an action under $\$ \S 1$ and 2 of the Sherman Act. See United States $v_{\text {. }} \mathrm{Co}_{0}$ lumbia Steel Co., 334 U.S. 495, 503-7 (1948); Rostow, Monopoly under the Sherman Act-Power or Purpose?, 43 ILL. L. Rev. 745, 785-7 (1949). Congress has received recommendations that more cooperation with the antitrust program be required from the various government agencies. See STAFF REPORT, op. cit. sipra note 131, at 14. 
is a restatement of the problem, rather than a solution. The question of identifying the factual meaning of the operative word "competition" has given rise to a trichotomy of tests: ${ }^{185}$

(1) Whether there is concentrated control of the market in the industry concerned, i.e., whether there is a lack of alternative sources of supply available to the buyer, or alternative buyers from the point of view of the seller. ${ }^{136}$ This is the structure test.

(2) Whether the conditions in the industry are such as to put a premium on business vitality-production, efficiency, invention, and reasonable price flexibility in response to reductions in cost. ${ }^{137}$ This is the performance test.

(3) A compromise, both factors to be considered simultaneously. ${ }^{189}$ This may be called the optimum benefit test.

The debate over the "new" Sherman Act is couched in terms of the meaning of "competition." ${ }^{139}$ Behind it lies the fact that not all industries can be dealt with according to generic legal formulae. The structure test is closely allied to the basic tenets of the American free enterprise system; strictly applied, it would lead to a large degree of atomization and a corresponding revival of small business. ${ }^{140}$ But it is at least doubtful that all industries should be atomized. For technological reasons, some degree of bigness must

135. See McDonald, Businessmen and the Sherman Act, Fortune, Jan. 1950, p. 104. "Competition" under the "new" Sherman Act probably does not refer to the pure competition of the classical economists, but to "workable competition," the availability of alternatives, explained in Clark, Tozwards a Concept of Workable Competition, 30 Axt. Econ. Rev. 241 (1940). See Mason, Current Status of the Monopoly Problem in the United States, 62 HARv. L. REv. 1265, 1267-8 (1949).

136. See Edwards, Maintaining Compertion 92-7 (1949); Edwards, Preserving Competition versus Regulating Monopoly-Can the Antitrust Lazus Preserve Compatition?, 30 AM. ECoN. REv. SUPP. 164, 170-1 (1940); Rostow, Monopoly under the Shermar Act-Power or Purpose?, 43 In. L. REv. 745, 778 (1949), A more stringent version of this test has been proposed recently: that the essence of the antitrust laws is that all business must be conducted in a competitive fighting spirit. See Callmann, The Essence of Antitrust, 49 Coc. L. REv. 1100, 1109-10 (1949).

137. See Adelman, Integration and Antitrust Policy, 63 HaRv. L. Rev. 27, 41-50 (1949) ; Adelman, Effective Competition and the Aititrust Laws, 61 Hatv. L. REv. 1289, $1302-4$ (1948).

138. See Mason, Current Status of the Monopoly Problem in the Unitcd States, 62 HARv. L. REv. 1265, 1280-3 (1949).

139. The word can apparently be used to justify almost any type of economic behaviour. At hearings before a Senate Committee in 1948, for example, a spokesman for Bethlehem Steel was asked why a price raise instituted by Bethlehem exactly paralleled a prior one by United States Steel. His reply was that "one of our salesmen learncd that the United States Steel Co. had increased the price, and so, to be competitive, we increased it also." Quoted in Rostow, Monopoly under the Sherman Act-Powicr or Purpose?, 43 ILL. L. Rev. 745, 783 (1949). Cf. United States Matsters Association v. FTC, 152 F.2d 161, 164-5 (7th Cir. 1945).

140. See Rostow, Monopoly under the Sherman Act-Pozver or Purpose?, 43 Inu. L. REv. 745, 790-3 (1949). 
be tolerated. ${ }^{141}$ The performance test is designed to meet this difficulty. It follows more closely the lines of the British Monopolies Act; its basic criteria are the benefits attributed to competition, whether or not a competitive market structure exists in fact. ${ }^{142}$ Either test may be economically desirable in a given situation-hence the compromise optimum benefit test-, but the combination of the two leaves unanswered two basic questions: how to decide which should be applied, and what to do with those sectors of the economy where effective competition is not possible.

The conflict is thus in reality not over the scope of the antitrust laws, which apply to all monopoly, but over the remedies applicable to various industries. Some of the necessary remedies the antitrust laws do not supply. The government should have the power to take action against industrial concentration whether the appropriate action involves atomization, supervision to prevent abuse, or continuing regulation. But the decision as to precisely what result is desired from particular government action must be made carefully by personnel oriented towards a positive integrated program. There are certain areas-communications, municipal power supply, and the like-where competition is not feasible, and there are further areas where it may be economically disastrous. A dual approach is needed, consisting of regulation, or at least supervision of economic policies, in those areas, and restoration of effective competition in all others. The policy of this plan may be briefly defined as decentralization of monopolistic economic power wherever possible, and democratization through public control wherever not. The system to which it leads is an adaptation to a mechanized age of the traditional policy of American antitrust legislation.

Implementation of this program would not require drastic rewriting of the antitrust laws. The Federal Trade Commission Act ${ }^{143}$ and the Clayton Act, ${ }^{144}$ with Section 7 amended to prohibit merger by purchase of assets as well as by purchase of stock, are adequate to deal with the business methods which may lead to monopoly power. The Sherman Act permits dissolution and divestiture. Recommendations to the legislature have already been made which are sufficient to lay the groundwork for an approach to existent concentration of economic power. ${ }^{145}$ The first action to be taken is an in-

141. See, e.g., Edwards, Matnranning Coarpetrion 156 (1949). For a brief categorization of conflicting results following application of the structure test without regard to business performance, see Mason, op. cit. sipro note 138, at 1269-71. Cf. Edwards, Preserving Competition versus Regulating Monopoly-Can the Antitrust Latus Preserve Competition?, 30 Axr. Econ. Rev. Supp. 164, 166-7 (1940); Rostow, A Reply, $57 \mathrm{~J}$. PoL. ECON. 60 (1949).

142. See, e.g., Bain, Rostow's Proposals for Petroleum Policy, 57 J. Por. Ecoir. 55 (1949) ; Mfason, op. cit. supra note 138, at 1267-8, 1276; Adelman, Effective Compclition and the Antitrist Lazes, 61 HARv. L. REv. 12S9, 1349-50 (1948).

143. 38 StaT. 717 (1914), 15 U.S.C. $\$ 41$ et. seq. (1946).

144. 38 StAT. 730 (1914), 15 U.S.C. \$ 12 et. seq. (1946). See note 112 supro.

145. StafF Report, op. cit. supra note 131, at 11-17. See also House Cosonrmes oN Sarall Business, op. cit. supra note 131, at 24-9. For citations to leading industry-by- 
dustry by industry analysis by the FTC in cooperation with other executive agencies. This can be initiated by executive order. It should be followed by systematic and coordinated action by the FTC and the Antitrust Division of the Department of Justice. For purposes of the program outlined above, the atomization of industries designated by the FTC findings as susceptible to decentralization can be effected through court proceedings brought by the Antitrust Division. ${ }^{146}$ The specific remedies asked should be based on detailed recommendations from the FTC. ${ }^{147}$ Where performance competition exists, and atomization is either unnecessary or undesirable, continuous quashing of restrictive practices can be effected through FTC cease and desist powers. Industries in which dissipation of monopoly control is not feasible can best be regulated under separate legislation, authorizing, for example, a permanent commission to control and collaborate on the economic policies within the industry. ${ }^{148}$ Until legislative action is taken, the antitrust laws and regulatory powers of existing executive agencies afford a means of supervision of the industry to the extent of prevention of abuses.

This program constitutes a partial acceptance of the British approach

industry studies that have aiready been published, see footnotes in Bain, Price and Production Policies in Ellis, A Survey of Contemporary Economics 129 (1918).

146. This is necessary under existing law since the remedies available to the FTC are limited to what can be accomplished through a cease and desist order. 38 STAT. 717, $\S 5$ (a) (1914), 15 U.S.C. $\$ 45$ (b) (1946). The administrative process, however, scems better suited to the trial of extremely complicated technological and cconomic issucs. See Edwards, op. cit. supra note 136, at 172-4. At any rate, close cooperation between the FTC as original investigator and the Antitrust Division as prosecutor is essential to the success of a planned attack. See Mason, op. cit. supra note 138, at 1284-5.

The current criteria of the Sherman Act seem adequate to give legal sanction to such an attack. See cases cited in note 121 supra. If future case law proves them to be inadequate, legislative expansion of the scope of the Sherman Act will be necessary before any program directed against concentration of economic power can be successfully carried out.

147. The FTC is specifically authorized to act as a master in chancery to ascertain and report an appropriate form of remedy. 38 STAT. 717, $\$ 7$ (1914), 15 U.S.C. $\S 47$ (1946). The section was used early, in United States v. Corn Products Refining Co., 234 Fed. 964 (S.D.N.Y. 1916), appeal dismissed, 249 U.S. 621 (1919). For some reason it has since been used rarely, if at all.

For treatment of the method of atomization of a particular industry, see Rostow, A National Policy fOR the OII Industry (1948). For discussion of supplementary legal changes that may be required, see Edwards, Maintaining Compermirion 133-55 (1949).

148. Nationalization might in fact be the cheapest and most efficient method of handling marginal "sick" industry. Since even the Progressive Party has declared itsclf against "socialism" and for "capitalism," however, this is probably politically impossible.

For examples of particularized industry control, see Agricultural Adjustment Act of 1938, 52 Stat. 31, 7 U.S.C. $\$ 1281$ et seq. (1946); Atomic Energy Act of 1946, 60 Stat. 755, 42 U.S.C.A. $\$ 1801$ et seq. (Cum. Supp. 1949); Civil Aeronautics Act of 1938, 52 Stat. 977, 49 U.S.C. $\$ 401$ et seq. (1946) ; Interstate Commerce Act, 24 SinT. 379 (1887), as amended, 49. U.S.C. \$1 et seq. (1946). 
to the problem of monopoly. ${ }^{149}$ The compromise is necessary. Decentralization of power cannot be achieved in all industries. Attempts to thrust competition upon those industries in which decentralization is impossible leads to hard case law and economically undesirable results. The British scheme is based on three fundamentals necessary to successful antitrust administration: (1) coordination in overall policy and among the various government departments; (2) placement of responsibility for appropriate remedy in the hands of personnel specifically authorized to effectuate, and precisely instructed in, that policy; and (3) treatment of the problem of monopoly as simply an economic problem which the government has a duty to resolve. None of these principles necessitates a concurrent adoption of the British attitude that monopoly is inevitable. Under a program based on them, competition may have the opportunity to prove itself as a workable system in many industries where it is now absent. The alternative to a forthright stimulation of competition in areas where it is appropriate may be eventual adoption of the British plan in toto.

149. The program outlined is not intended to constitute a complete coverage of the field. Freedom of entry into the competitive arena, for example, could be stimulated by appropriate revision of the patent laws, including compulsory licensing provisions, and financial assistance to new enterprise through such government agencies as the RFC. For detailed proposals, see generally Enwards, Manntannma Cosrperrtion (1949); Starons, A Positive Prograje for Laissez Fatre (1934). 